\title{
The Artificialization and Politicization of the Geographical Space: A Theoretical Inquisition Into the Sociology of Human Identity and Individual Mobility
}

\author{
Dapo Thomas \\ Lagos State University, Lagos, Nigeria.
}

\begin{abstract}
The geographical space is the void space that nature creates for human habitation. It is simply a natural space for man, animals, and other creatures. It is the natural environment which accommodates the waters, the plants, the flowers, the trees, and the oceans; all the features facilitate the process of romanticization and socialization between man and his space. It is the same space that man has converted into a political establishment by creating artificial barriers all over to delimit physical movements of individuals across the space, to establish political and social identities for all citizens of the earth via political and geographical platforms, and to locate states within some fixed territories for the purpose of their governmental activities. The dilemma that has been created by the politicization of the geographical space in terms of forced or inherited identity and the automatic loss of identity choices to others, needs to be interrogated using a theoretical construct and a methodological approach. The migration theory needs to be contextualized with another appropriate conceptual framework like universal man theory to determine the dynamics of human mobility, constraints and bathers created for political and administrative expediencies. The question of identity-legitimation would naturally be a central theme in this discourse. Who possesses the right, obligation, authority and power to establish an identity for man? Is it the state? The parents? The environment? What is even the role of the creator Himself in identity-allocation? In investigating this sociological rhetoric, the study aimed at interrogating the artificiality of the political structures and how these structures infringe on a man's birthright to explore the vastness of his environment from one end to the other without being inhibited by political and administrative creations. We further establish the fact that political artificiality is in obvious conflict with some natural privileges that a man was entitled to. Some of these privileges include the choice to belong to any part of the space that he so desired to adopt for settlement. Until we resolve this conflict, we may not be able to determine if migration is a political or economic act or a spiritual exercise that man must undergo to complete the process of his existential mobility.
\end{abstract}

Keywords: identity-legitimation, artificiality, political establishment, geographical space, socialization

\section{Introduction}

The geographical space was a creation of nature. It preceded humanity. It has all the features for human habitation: There were the mountains, the caves, the oceans, the rivers, the seas, the jungles, the forests, the plants, the trees, and the shrubs. Science has not disputed the fact that with the mountains came the mammals,

Dapo Thomas, Lecturer, Department of History and International Relations, Faculty of Arts, Lagos State University. 
the apes and man; with the oceans and the seas came the fossil fishes and the fishes; with the jungles and forests came the animals and the birds. Then suddenly, man appeared at a time that preceded history. This is still in dispute. For instance, H. A. Clement, author of The Story of the Ancient World (1971) wrote:

The first creatures that really resembled men appeared about 600,080 years ago. We do not know very much about them, as only a few remains, like skulls, have been discovered...

... it is thought, from the very narrow shape of the Jaws, that these early creatures could not speak, as we understand the world. But they could probably light fires, as ashes have been discovered along with their remains... these early creatures were not true men. The first real men appeared about 35,080 years ago, and must have driven out the earlier creatures. (p. 20)

In their own accounts on the first man, Roberts and Westad, alluded to the fact that 100 million years ago or so, primitive mammals were of two main sorts. According to them, one was rodent-like, remained on the ground, and the second took or had taken to trees. They explained:

In this way, the competition for resources was lessened and strains of each survived to people the world with the creatures we know today. In the second group were the prosimians. We are among their descendants, for they were the ancestors of the first primates... During this time, geography counted for much in their evolution... changes would not happen quickly but it is likely that fragmentation of the environment caused by geographical disturbance led to the isolation of zones in which, little by little, the recognizable ancestors of many modern mammals appeared. Among them are the monkeys and apes. These monkeys and apes represent a great evolutionary stride. (Roberts \& Westad, 2013, p. 6)

Appealing for caution in ascribing too much scientific significance to their narrative on human evolution, Roberts and Westad explained that the evidence they have on it, though fragmentary, suggests that some 15 or 16 million years ago a very successful species was widespread throughout Africa, Europe, and Asia. This species probably a tree-dweller and specimens not very large, weighing about 40 pounds, developed or transformed with time. They clarified further:

We have no direct knowledge of its immediate forebears or descendants but some kind of fork in the road of primate evolution seems to have occurred to its later relatives, often called Huminids, around 5 million years ago. While one branch was to lead to the great apes and chimpanzees, the other led to human beings...

This is not very different (allowing for the generous stretches of time and approximation available in pre-historic chronology) from the dating of "Lucy", formerly the complete specimen of Australopithecus discovered (in Ethiopia). (Roberts \& Westad, 2013, p. 7)

The absence of credible and unified or universal scientific explanations for the creation of the earth (universe) and the evolution and the emergence of the first man, has made a recourse to the biblical narrative imperative. In the Bible, GOD was said to have created the heaven and the earth dividing the waters which were under the firmament from the waters which were above the firmament. Unlike the pseudo-scientific narratives, the biblical narrative is full of command-creations like "let there be", "and it was so", "GOD said..." and "GOD made..." and so on. For instance, in one of the creation "instructions", GOD said, "let the waters under the heaven be gathered together unto one place, and let the dry land appear, and it was so" (James, 2004, p. 9).

According to the account, GOD called the dry land Earth, and the gathering together of the waters called the seas and GOD saw that it was good. In explaining how the trees and the plants evolved, the biblical account stated that GOD commanded the Earth "to bring forth grass and the fruit tree-yielding fruit after its kind, whose seed is in itself, upon the earth; and it was so". 
After His dazzling and miracle-inspiring galaxy creation, GOD "decreed" again the creation of birds, fish, whales, cattle, creeping thing, and beast of the earth. This is how the Bible puts it:

And GOD said, let the waters bring forth abundantly the moving creature that hath life, and fowl that may fly above the Earth in the open firmament of heaven... GOD created Great whales and every living creature that move, which the waters brought forth abundantly after their kind and every winged fowl... GOD said, let the earth bring forth the living creature... cattle and creeping thing, and beast of the earth... and it was so. (James, 2004, pp. 20-25)

In describing the creation process of man, the Bible recalls that GOD was worried about who would look after all His creatures that He had commanded to be "fruitful and to multiply". He, therefore, in consultation with some unseen aides, decided to "make" man. His words: "Let us make man in our image, after our likeness and let them have dominion over the fish of the sea, and over the fowl of the air, and over the cattle, and over all the earth, and over every creeping thing that creepeth upon the earth".

Though this statement is confounded and coded, especially the aspect on "image" and "likeness", the interesting thing was that in creating man, the Bible says: "GOD formed man of the dust of the ground and breathed into his nostrils the breath of life and man become a living soul". But the evolution of the woman did not come through the "dust ritual". Hers was a bit of science - call it "spiritual science". In creating the woman, the Bible says GOD caused a deep sleep to fall upon Adam, and he slept. It was from one of the ribs that He took from Adam that He made the woman.

In an instruction, He had given that earlier when He was "scanning" man in His thoughts, GOD said to both man and woman: "be fruitful and multiply, and replenish the earth, and subdue it: and have dominion over the fish of the sea, and over the fowl of the air, and over every living thing that moveth upon the earth".

The first places to be categorically named or mentioned in the Bible are Havilah and Ethiopia. Though Eden was described as a garden, whatever it was, left no trace of its shadows afterwards if it truly and really existed. To some extent, the discovery of "Lucy" formerly the complete specimen of Australopithecus, in Ethiopia conveys just an insignificant evidence of connectivity between the historical and the biblical narratives. Though Roberts and Westad (2013) affirm that tools found in Ethiopia are the oldest which we have (about $2 \frac{1}{2}$ million years old) and they consist of stones crudely fashioned by striking flakes off pebbles to give them an edge (p. 9).

\section{Migration, Settlements and Civilization}

Once the issue of the first men has been settled either scientifically or biblically, even though some of the accounts are still shrouded in mystery, and as such, lack the kind of credibility that can determine its finality. What followed were migration and human settlements in various parts of the earth, from Africa to Asia, from Europe to Americas. There were cyclical human movements, horizontal and vertical settlements in different parts of the world. These human movements and settlements have been linked with civilization. Breaking away from the Ice Age, Old Stone Age, and Neolithic or New Stone Age, men become socialized and civilized. Their personae had to adapt to the changes that were happening dramatically and dynamically everywhere around their environment.

According to Clement (1971), towards the end of the New Stone Age, and still more at the beginning of Age of Metal, after the use of copper and bronze had been discovered, man became more civilized. Man learned to live peacefully with his fellow-creatures, to organize a government, to erect buildings and to make advances in the arts and crafts (p. 2). The history of man is tied to civilization and both have their challenges. 
As for the history of man, the major challenge was how to survive in his environment, how to sustain himself on the things he can find around him, and how to defend himself against wild and ferocious animals in his environment. His mobility therefore was tied to these fundamental challenges which he had to overcome if he must dominate his environment. Though man appeared as the most creative and instinctive of all creatures, he needed to develop the capacity for dominion before he could take over the leadership of his environment.

In order to achieve this, man began to explore the resources and implements around him. He tapped the resources he could find around; for those he needed and he could not find around him, he started searching and exploring around and about him in order to find what to eat and what to use in guaranteeing his survival. The search for food and implements and tools of defense forced man to move from one end of the world to the other. In doing this, he encountered obstacles in terms of making the right choice about his place of settlement and about his security. In the words of Clement, man was concerned about fertility and defense. But he noted that it was not enough to be able to grow food; but that you must be sure that you can protect your fields and crops from invaders before you will settle down. In addition, it is pertinent to erect great buildings and study the arts of peace.

The term "invaders" poses a serious riddle about human identity in an ancient world that was yet to evolve structures of politics and governance. If in the pre-historic period every man was moving around in search of food, shelter and security, why should anyone be referred to as an "invader" as if there was a modern state with territorial and political paraphernalia? This term "invader", because it was not challenged and questioned, must have been responsible for the many derogatory terms that came with the emergence of the modern state. Terms like "migrants", "refugees", "fugitives", "visitors", "immigrants", "nomads", "asylum seekers", etc. are derogatory emblems disparaging the human identity. Regardless of our disposition to the stories of creationbiblical, geographical, scientific and mythical - every man was born, or evolved in a particularly environment with the freedom to explore the vastness of the space to his ultimate satisfaction. Mobility, according to Peter Adey (2010), is ubiquitous; it is something we do and experience almost all the time (p. 1). For Nigel Thrift, even space itself is characterized by this mobility and movement; every space is in constant motion. Aiwah Ong writes how mobilities have "become a new code word for grasping the global" and the new and extensive ways in which we live. In the words of Adey, without mobility we could not live. Without mobility we could not get to work or to the nearest source of food, neither could we stay healthy and fit. We could not make and sustain social relationships, and we could not travel to far away or nearby destinations.

If we succumb to this artificiality where one's mobility and exploring capacity are constrained by physical barriers and political structures, we are providing some form of legitimacy for such creations like "settlers", "indigenes" "aborigines" and for "the rest of us". We have to go about with the toga of "invaders" and "migrants". If the version of the creation story in the Bible is to be believed, then everyone of us must be "migrant", "fugitive", and "vagabond". This is evident from the manner in which GOD treated man after his fall in the Garden of Eden. The Bible says "Therefore, the LORD GOD sent him forth from the Garden of Eden, to till the ground from whence he was taken". That "whence" was not mentioned. Much later in Genesis 4, verse 14, GOD cursed Cain for killing his brother Abel and categorically called him a "fugitive" and a "vagabond" in the earth. If we are descendants of these "first men" as the Bible has presented, is it not logical to infer that we are all "fugitives" and "vagabonds" in the earth? Even if we are to rely on the geographical and scientific creation stories, we still cannot escape from this fugitive and vagabond status as long as we were not created or born as immobile objects/creatures. If, therefore, this fugitive and vagabond status conflicts or casts 
aspersion on our identity as humans, it is because we have not truly identified our real identity. The question then is what is identity?

In their book on identity theory, Peter Burke and Jan Stets (2009) define identity as: "The set of meanings that define who one is when one is an occupant of a particular role in society, a member of a particular group, or claims particular characteristics that identify him or her as a unique person" (p. 3). But in a very loaded definition, Lawler (2014) says "identity itself is a social and collective process and not, as Western traditions would have it, a unique and individual possession" (p. 2).

Expanding further on what he calls "Identity, connection and value", Lawler quotes Sygmunt Bauman as saying that "the underclass is denied the right to claim an identity, as distinct from an ascribed and enforced classification". In other words, an identity is imposed and there is no "official" space allowed where this may be contested or a different identity affirmed. According to Lawler (2014):

In "softer" versions, this group might be designated "the socially excluded" or in another context "refugees"... and when concerned with those others who are seen as threatening the nation's border, "illegal immigrants", "economic migrants" or even "terrorists". None of these forms depend on those who are designated as such choosing or claiming such identities. Those with the power to name can identify both themselves and those without such power... Individuality, it seems, is not available to all. To be seen as a member of the "underclass", as to be a refugee, is to be positioned as without a meaningful identity: simply to be made part of a "mob". Characterizing persons as "mob-like" divests them both of identity and of value. (pp. 182-183)

In examining and analyzing the implication of divesting of identities, Lawler (2014) says that it reminds us of how dangerous it is to conceptualize identities that can be forged on the basis of "us" and "them". In other words, identities can be used to draw lines between who belongs and who does not (p. 183). This identity divestment diminishes the personality of the individual in question as he begins to worry about who he really is. The author of the book Personality Theories, Barbara Engler (2009), contends that a complete search for the definition of personality will take us back to the early history of the human race, back to the time when the first person asked, "Who am I"? thereby reflecting on his or her identity (p. 2).

In describing what personality means, Carl Rogers, a personality theorist, submits that the personality or "self" is an organized, consistent pattern of perception of the "ll" or "me" that lies at the heart of an individual experience. This is why such deprecatory terms like "invaders", "illegal immigrants", "fugitives", "visitors", "refugees", "nomads", "white" and "black" conjure the imagery of "aristocratic imperialism" and are prejudicial to those affected. This kind of treatment to those concerned elicited different comments and reactions at different stages of human history especially in the United States. For instance, Frederick Douglas exclaims in a paper he wrote on "Colonization":

We are of the opinion that the free colored people generally mean to live in America, and not in Africa-for two hundred and twenty eight years has the colored man toiled over the soil of America, under a burning sun and a driver's lash - plowing, planting, reaping, that white men might roll in ease... and now that the moral sense of mankind is beginning to revolt at this system of foul treachery and cruel wrong... shame upon the guilty wretches that dare propose, and all that countenance such a proposition. We live here-have a right to live here, and mean to live here. (Jacobs, 1981, p. 6).

When this statement is located in its proper context, especially with regards to the assertiveness of the statement and its emphatic pronouncement like "We live here, have a right to live here and mean to live here", one is overwhelmed by the proclamation which probably was made to draw attention to man's natural 
right to navigate or settle or live anywhere he considers suitable and conducive for his existence and survival. But how does one understand the politics of national identities without comprehending its linkage with migration.

\section{Between Migration and Mobility}

So, what is migration? In her book, Crisis and Migration, Anna Lindley (2014) wrote: "Migration is conceptualized as human movement articulated in a particular way across space and time. Like all mobility, migration is a spatial phenomenon involving movement between distinct places-locations imbued with meaning and power" (p. 7). Elucidating the concept further, Lindley (2014) says that "migration more specifically refers to people changing their place of residence, where they live on a habitual basis, embracing not only the physical structure, but also in some sense the wider community in which they live... thus, the term is associated with the crossing of some kind of socially significant frontier" (p. 7).

Linking or drawing contrast between navigation and immobility, Lindley admits that though migration is somehow problematic and politicized, there are institutional frameworks which powerfully shape how we understand migration in terms of time and space. Migration, he writes, is clearly located in time as an identifiable event which occurs when a person moves physically from one place to another, through this act is embedded in a way of earlier and subsequent social processes which are also viewed as facets of migration. His words: "Indeed for migration to have occurred, a story of some substantial duration is deemed necessary: rather than just visiting, the migrant is establishing some kind of regular life in the place of destination whether on an open-ended or more temporary basis" (Lindley, 2014, p. 8).

In what can be described as a very myopic and policy guide, Christina Boswell and Andrew Geddes (2011) describe "an international migrant" as someone living outside their country of origin either regularly or irregularly for a period of 12 months or more (p. 2). As if this was not irritating and insulting enough, they went further to spell it out this way: "International migration refers to movement from outside the EU by people who are not nationals of a member state. EU mobility however, refers to nationals of EU members states - exercising their rights of free movement as EU citizens" (Boswell \& Geddes, 2011, p. 3).

This distinction between migration and "international migration" is a unique dimension. Its imperativeness as a policy guide has compromised its globalised and historical value. Migration is as old as history. For any institution or group of people to present migration as modern day "pilgrimage" or "tourism" is the height of intellectual deception. There is nothing like "international migration" and there should be nothing like that. The EU and other international agencies and institutions which are trying to dichotomize migration into localized and internationalized sections are obviously doing so to promote political expediency that justifies the establishment of political structures and erection of physical barriers that keep people away from exercising a natural franchise that guarantees them an inalienable right to move freely in and within the geographical space that nature endows them with. It must be noted that every settlement is a process of migration. To now pretend as if some settlements were made from heaven or an outer space without evidence of migration is nothing but sheer illusion and hypocrisy.

The story of the Israelites in the bible tells of how the migration of a whole tribe or race wiped off another race (Canaanites) from a land which they originally occupied. The Canaanites were possibly overwhelmed by the huge numbers of Israelites that "invaded" their 'colony' or were subdued by a tribe in possession of superior implements of war. Whether the Canaanites were all slaughtered, assimilated, culturized, driven out of 
"their land" are still within the realm of historical conjectures. This was not the only case of how migration changed the history of a location, a land, a people, a race and a collectivity.

The navigations and explorations of both the South and North Americas by the Italian navigator, Amerigo Vespucci and Christopher Columbus, an Italian mariner, John Cabot, Ponce de Leon, Alonzo Alvarez, Francisco Gordillo, Pedro de Quexos, a slave trader and Lucas Vasquez between October 12, 1492 and 1528, were all in the processes of migration. Though some of these "navigators and explorers" created the impression that they "discovered" a "New World", there was abundant evidence that before them, a tribe of Indians was already settled in most parts of South and North Americas.

According to Setmour Schwartz (2000) in his famous book This Land Is Your Land, when Ponce de Leon was continuing his voyage of exploration around the Peninsula past the Florida Keys, and then North, landing around Yompa Bay in 1521, he was ambushed by Indians near Tampa Bay and was fatally wounded (p. 15).

In another instance, the initial penetrations into the interior of North America were being made at the directive of the Spanish conquistadores who had established footholds in Mexico and Cuba. By 1521, writes Schwartz, Cortes had gained control of Tenochtitlan and the entire Aztec Empire. The natives there told stories of the legendary seven cities of "Ciboja" (a Spanish name derived from the Indian word for buffalo) (Schwartz, 2000 , p. 18). So, the natives being referred to were Indians who had earlier settled or occupied the place.

Cabeza de Vaca also recorded in his book the second name (after Florida) used to designate a large portion of "our country". "Apalachen", derived from the name of small Indian Village in Northern Florida (Schwartz, 2000, p. 18).

Like the Canaanites, the band or tribe of Indians that sprawled all over South and North Americas before the coming of new settlers had been subdued, "conquered", outnumbered, "imperialized" or socially humiliated. Not too sure whether this is mobility or migration, Fracheti and Spengler explain that the term mobility refers to geographic travel and more specifically the strategic movement of groups on a regular or prescribed schedule to capitalize on diverse resources to meet and interact with others to explore an unfamiliar environment. To them migration "refers to directed, territorial (trans-regional) relocations that result in populations changing the epicenter of their practical (localized) mobility orbits".

Shedding more light on how the Europeans or the whites came up with the idea of movement control in their different domains, John Torpey argues in The Invention of the Passport that European States have primarily shown "great interest in identifying and controlling the movement of their subjects/servants in the 19th and 20th centuries" (Vigneswaran \& Quirk, 2015, p. 39). According to Torpey, it was during this period that states came to effectively monopolize the legitimate means of movement and exert control over subject populations and related patterns of mobility across internal and external borders.

The idea of movement control mechanisms is an unfair infringement on the right of those that Paivi Kannisto (2016) refers to as "Global Nomads", in his book, Global Nomads and Extreme Mobilities. Describing the global nomads, Kannisto (2016) says "they are people who live in the margins of societies", those who are homeless, or at home wherever they happen to be. These are people who have left their countries of origin behind and have no ties to any geographic place, therefore being location-independent. He reveals further, "they may remain in their chosen destinations for some days, weeks, or months, but in the end they always move on, belonging nowhere in particular" (p. 1).

He reflects on the lifestyle of the global nomads in this way: 
Global nomads live in the margins of societies. Like other migrants and multi-mobile people who reside and work in various places, they question the conventional divisions between home and abroad, settled and mobile, work and leisure. Many of them have given up a regular income and the associated work ethic based on the moral values of toil and diligence, instead searching for alternative ways of supporting themselves. They have neither health care nor private insurance but try to function without these support structures. (Kannisto, 2016, p. 1).

Amplifying his theory on global nomads, Kannisto questions whether global nomads' lives are as antithetical to societies' conventions as the definition suggests. He contends that individualization of cultures, the rise of diverse lifestyles and increasing mobilities also shape and challenge contemporary societies. People value their independence and mastery of their own lives.

The relevance of mobility, combined with the relevance of place, makes questions of immigration and citizenship both pressing and contested in countries around the world. The global nomads may not wish to romanticize with a particular society. They derive necessary excitement from their movement up and down without any form of citizenship or national identity. But this delimits them as individuals. In the words of Benhabib and Resnik (2009), "a simplistic presumption is that citizens residing in a given nation-state are in a reciprocal relationship with that country, recognized as members, entitled to rights, protection, material support, and political loyalty. Non-citizens lumped together into an undifferentiated whole sit outside that circle of rights and obligations" (p. 2)

\section{Conclusion}

Some of the mysteries of history and human existence can hardly be resolved through scientific experimentations and historical conjectures. I am bewildered by the fact that history has not successfully proven or clarified the conflict between individual and national identities particularly as it affects the migration of people from one place to the other and individuals with dual or multi-identity status that places them neither here nor there. When a man is tagged migrant (legal or illegal) in a land which may turn out to be his/her source of initial migration, and is subjected to an interrogation whose objective is to mock or ridicule his identity: a confusion created by the difficulty to identify with one of these societies in terms of values, culture, habits, idiosyncrasies, and orientations: things tend to get more complicated. Let me use a conversation between an interviewer and Samantha (not real name) to illustrate this identity tango. Samantha is a Nigerian born in England by a Nigerian father and a British mother. Here is the dialogue as captured in an unpublished work titled: Where are you really from by Rachael Owhin (2015), an Oxford University graduate:

Interviewer: Where are you from?

Samantha: Nigeria

Interviewer: How would you describe your Nationality?

Samantha: British

Interviewer: Even though as we've just discussed, you're from Nigeria.

Samantha: Yeah, but regardless, like I said at the very beginning, I have a British passport and that has preeminence (laughter)

Interviewer: So, why when people ask where you're from why would you not say England?

Samantha: Long pause...mmm that's interesting

Interviewer: What nationality do you identify with? 
Samantha: Pause

Prrrrrrrrr

Interviewer: You don't have to choose one, you can just describe it?

Samantha: But the thing is, it's weird because I'm British through and through, but I'm still British like the heart of me is British. I'm not a Nigerian Brit-I'm a British Nigerian. It's just, that's it, I'm British through and through...although... that's interesting. Yeah. I'd say being British impacts me more and influenced me more, I identify with that more.

Interviewer: What do you mean by "impacts and influences you more"?

Samantha: Like it's who I ammmm, like at the end of the day who am I, yeah I'm Nigerian to a certain degree but I'm more British than anything but I have Nigeria running through me you know it sort of, the culture impacts the way I speak but so does the British culture, impacts the way I eat, impacts the way I act sometimes, (laughter) yeah most of the time actually. But I'm British, yeah, I'm British.

Interviewer: Where is home for you?

Samantha: Home is Wembley to be honest. Home is Wembley, I feel very attached to my area... Home is London but more importantly home is, home is, Wembley, yeah.

Interviewer: So, not Nigeria?

Samantha: Nooo again, I haven't had the chance to establish that as my home I haven't got any connections there. Although I have family, who I don't speak to, I haven't got any real real real connection to make it feel like it's a home for me.

Interviewer: So where do you feel as sense of belonging to?

Samantha: Wembley, although I guess the bigger picture is Britain, or England, whatever you want to call it, but definitely Wembley, definitely. (pp. 58-60)

When some societies label some people with all kinds of derogatory terms, what it means is that we have a divided humanity. As if this was not divisive enough, erecting and establishing political and physical structures to restrict and control the movement of humans, attests to the appropriation of authority by the state to have legal and political control over human identity. How, for instance, would the Americans feel if the Indians they overwhelmed and subdued on "their land" correctly label them "invaders" in view of available evidence showing that before the coming of Amerigo Vespucci, the Italian, after whom the land was named, the Indians had established themselves in the place.

Agreeing that erection of structures and creation of political establishments tend to hasten development process and enhance systemic structuralization, this situation should not, under any circumstances, lead to identity stigmatization and divisive practices. My submission is that I should be free to move beyond borders without being tagged: "a visitor", "a migrant", "illegal immigrant", "a refugee” or an "asylum seeker" etc. Even if you call me a "nomad", I have the right to protest because the only identity which gives me the respect I deserve as a human being is the name that I bear. Any other label rubs me of the kind of personality I crave for myself by living my life in my way. I am not existing at the mercy of any individual, country, system, power, group or collectivity. I am a creation of nature. In fact, I can say I am a creature of GOD and therefore, I am at liberty to exercise my inalienable right to transverse the length and breadth of the geographical space that nature confers on me. 


\section{References}

Adey, P. (2010). Mobility. New York: Routledge.

Benhabib, S., \& Resnik, J. (2009). Migrations and mobilities: Citizenship, borders and gender. New York: New York University Press.

Boswell, C., \& Geddes, A. (2011). Migration and mobility in the European Union. London: Palgrave Macmillan.

Burke, P. J., \& Stets, J. E. (2009). Identity theory. New York: Oxford University Press.

Clement, H. A. (1971). The story of the ancient world. London: Pitman Press.

Engler, B. (2009). Personality theories. Belmont: Wadsworth Cengage Learning.

Jacobs, S. M. (1981). The African nexus: Black American perspectives on the European partitioning of Africa, 1880-1920. Wesport:

Greenwood Press.

James, K. (2004). Holy Bible Reference Edition. Belarus: Jet Move Publishing.

Kannisto, P. (2016). Global nomads and extreme mobilities. Survey: Ashgate Publishing Limited.

Lawler, S. (2014). Identity: Sociological perspectives. Cambridge: Polity Press.

Lindley, A. (Ed.). (2014). Crisis and migration: Critical perspectives. New York: Routledge.

Owhin, R. (2015). Where are you really from? (M.A. Dissertation, Department of International Relations and School of Anthropology, University of Oxford) (Unpublished).

Roberts, J. M., \& Westad, O. A. (2013). The penguin history of the world. London: Penguin Books Ltd.

Schwartz, S. I. (2000). This land is your land. New York: Harry N. Abrams Inc.

Vigneswaran, D., \& Quirk, J. (Eds.). (2015). Mobility makes states: Migration and power in Africa. Philadelphia: University of Pennsylvania Press. 